\title{
MENGENAL HERMENEUTIKA MELALUI MUHAMMAD SHAHRUR DAN HASSAN HANAFI
}

\author{
Ahmad Haromaini \\ aharomaini@unis.ac.id \\ (Dosen Fakultas Agama Islam Universitas Islam Syekh-Yusuf Tangerang)
}

\begin{abstract}
Abstrak:
Tafsir sebagai bagian dari studi Al-Qur'an menjadi satu aktifitas yang diyakini mampu memenuhi kebutuhan dalam menampakkan keluhuran kandungan Al-Qur'an. Hassan Hanafi dan Muhammad Shahrur berusaha melakukan kritikkan terhadap penafsiran klasik yang sudah berkembang sejak lama, mereka mengajukan metode penafsiran yamg berbeda terhadap Al-Qur'an yakni hermeneutika, metode penafsiran ini dikembangkan sebagai jawaban dan respon Al-Qur'an dalam menjawab persoalan ummat manusia dan dianggap mampu -secara berbeda dengan model penjelasan al-Qur'an dengan yang lalu- menjelaskan Al-Qur'an secara komprehensif.
\end{abstract}

\section{Kata Kunci: Hermeneutika, Muhammad Shahrur, Hassan Hanafi}

\section{A. Pendahuluan}

Al-Qur'an hadir sebagai sebuah kitab suci dan memiliki tugas mempedomani para pemeluknya maupun di luar pemeluknya. Namun demikian, M. Abduh ${ }^{1}$ menyebutnya bukan sebagai kitab sejarah, kedokteran maupun yang lain. Karena AlQur'an sendiri yang mentahbiskan dirinya sebagai petunjuk, tidak hanya kepada ummat muslim maupun kepada seluruh ummat manusia. Peran itu mesti dijalankan oleh Al-Qur'an dan tidak mungkin ditinggalkan, karena bagaimana tidak ia tinggalkan sedangkan ia secara eksistensi sebagai hidayah bagi semua ummat manusia.

Melalui Al-Qur'an, kitab suci yang mengkodifikasi Kalam Tuhan. Pesan-pesan Tuhan disampaikan kemudian dijadikan pedoman bagi ummat manusia agar mereka mampu menelusuri jalan kehidupan dan melakukan setiap tanggungjawab yang

\footnotetext{
${ }^{1}$ Muhammad Abduh, Tafsir Al-Qur'an alHakim, (Kairo: Dar Al-Manaar, 1947), jil. I, cet. keI, h. 4.
}

diemban dengan tuntunan Al-Qur'an. Oleh karena itu Al-Qur'an hadir bagi semua elemen manusia hidayah, ${ }^{2}$ petunjuk yang membimbing mereka dan menyampaikan hal-hal yang berhubungan dengan kebutuhan mereka, baik yang berkaitan dengan ketuhanan maupun yang bertalian dengan kehidupan dunia.

Nama-nama lain yang digunakan $\mathrm{Al}-$ Qur'an memang cukup beragam, penamaan tersebut sejatinya merepresentasikan Al-Qur'an, bahwa dari nama-nama tersebut ia hadir dengan beberapa pesan dan fungsi yang berbeda. Fungsi-fungsi tersebut tidak berdiri secara parsial, terpisah maupun tidak memiliki keterkaitan satu dengan yang lainnya. Di antara nama-nama tersebut ialah, $A l$ Qur' $^{\prime}{ }^{3}$ (bacaan) ini terdapat dalam beberapa surah di antaranya terdapat dalam QS. Yaasin, di mana Al-Qur'an dijadikan sebagai objek sumpah (muqsam bih) di

\footnotetext{
${ }^{2}$ QS. Al-Baqarah/2: 2.

${ }^{3}$ QS, Al-Baqarah/2: 185, QS, Al-An'âm/6:
} 19, QS, Yûnus/10: 15, dan QS, Yûsuf /12: 2, QS. Yaasin/36: 2, QS al-Isra/17: 106. 
saat nabi Muhammad saw. diragukan kenabian dan kerasulannya, ${ }^{4}$ al-Kitâb ${ }^{5}$ (buku), kata Kitab dalam al-Qur'an disebutkan hingga sangat banyak, baik dalam bentuk rafa', makhfudh, ${ }^{6}$ mulai dari penyebutan nama al-Qur'an sendiri, maupun nama-nama kelompok yang disematkan kepadanya, seperti ahl al-kitab yang ditujukan kepada kaum pemegang Kitab Taurat dan Injil dari golongan Bani Israil, kemudian nama lain yang direferensikan kepada al-Qur'an adalah kata al-Furqân, ${ }^{7}$ kata al-Furqan di samping sebagai nama al-Qur'an ia juga sebagai nama surah dalam al-Qur'an. Lalu nama selaian yang di atas adalah al-Dzikr, kata al-Dzikr yang berkaitan dengan alQur'an cukup banyak. ${ }^{8}$ Hudan $^{9}$, kata hudaan diartikan sebagai petunjuk, yakni ia hadir sebagai hidayah yang akan memberikan petunjuk kepada siapapun yang hendak mengambil darinya. Petunjuk dapat diartikan sebagai jalan yang mengantarkan seseorang kepada jalan kebahagiaan dan kesempurnaan di dunia dan di akhirat. ${ }^{10}$ al-Rahmah ${ }^{11}$ (kasih sayang), kata kasih saying diambil dari kata rahmah, nama ini sebenarnya juga merupakan nama lain Allah swt. al-Syifâ ${ }^{12}$

${ }^{4}$ Lihat Syaikh Hamami Zaadah, Tasfir Surah Yaasin, Maktabah Thaha Putra, tt, hal. 2.

${ }^{5} \mathrm{QS}, \mathrm{Al}-\mathrm{Baqarah} / 2$ : 2 dan QS, Al-Nahl/16: 64.

${ }^{6}$ Al-Maqdisi, Fath al-Rahman, Maktabah Dahlan, Bandung:tt, hal. 380-381.

${ }_{7}^{7}$ QS, Al-Baqarah/2:185, QS, Al-Furqân/25: 1.

${ }^{8}$ QS. Al-Hijr/15: 6, QS. Shad/38: 8, QS. AliImran/3: 58, QS. Shad/38: 1, QS. Al-Hijr/15: 9 QS. Al-Nahl/16: 44.

${ }^{9} \mathrm{QS}, \mathrm{Al}-$ Baqarah/2: 2 dan 185.

${ }^{10}$ Abi Bakr al-Jazairi, Aysar al-Tafasir, Madinah, Maktabah Al-'Ulum wa al-Himha, 2003, juz. I, cet. ke-6, hal. 5 .

89.

${ }^{11}$ QS, Al-A'râf/7: 52 dan QS, Al-Nahl /16:

${ }^{12}$ QS, Yûnus/10: 57 dan QS, Al-Isrâ/17: 87. (penawar, khususnya bagi hati yang resah dan gelisah), dan al-Mau'izhah ${ }^{13}$ (wejangan). Nama-nama yang diperkenalkan Al-Qur'an dari berbagi redaksi ayatnya memberikan petunjuk bahwa Al-Qur'an adalah kitab suci yang berdimensi banyak dan berwawasan luas. Ia hadir dari zaman ke zaman tidak henti-hentinya dibaca, dikaji, diaji, digali dan ditafsirkan, itu tidak karena mereka -dalam hal ini para mufassir dan pemaham-ingin menjadikan Al-Qur'an tidak hanya sebagai teks suci (scripture) tetapi lebih dari itu, mereka menginginkan Al-Qur'an bisa dijadikan sebagai petunjuk (seperti penamaan atas dirinya) dalam membimbing ummat manusia dalam menjalankan tugas kehidupan sehari-hari., sehingga setiap permasalahan terjadi dan berkembang di masyarakat bisa ditentukan solusinya dalam al-Qur'an. Dengan kata lain al-Qur'an harus dijadikan way of life bagi kehidupan mereka, dalam arti pemecahan berbagai jenis problematika yang dihadapinya senantiasa dibawah bimbingan Al-Qur'an.

Ke-hidayah-an ${ }^{14}$ Al-Qur'an sejatinya dapat diterima dan ditelusuri oleh siapapun. Hal itu menjadi sesuatu yang absolute 'mutlak' dan tidak lagi diberikan ruang publik untuk diskusi. Namun demikian tidak setiap mereka yang

\footnotetext{
${ }^{13} \mathrm{QS}, \quad$ Al-Mâidah/5: 46 dan QS, Yûnus/10:67.

${ }^{14}$ Kehidayahan Al-Qur'an akan menjadi jelas dan nyata dengan keberadaan tafsir sebagai disiplin ilmu yang memabahas dan mengkaji kandungankandungan Al-Qur'an. Bahkan menurut Rif'at Syauqi Nawawi bahwa yang menjadi target dan sasaran tafsir adalah agar hidayah Al-Qur'an benarbenar berfungsi sebagaimana ia dturunkan, yakni ia menjadi rahmat bagii seluruh manusia, tidak hanya orang yang beriman tetapi juga kepada mereka yang belum beriman. Lihat Rif'at Syauqi Nawawi, Rasionalitas Tafsir Muhammad Abduh, Kajian Masalah Aqidah dan Ibadah, Jakarta: Paramadina, 2002, cet. ke-I, hal. 87.
} 
menganuti agama Islam memahami secara mendalam makna-makna dan kehendak Al-Qur'an yang disampaikan dalam rangkaian ayat dan surat tersebut. Oleh karena itu, tafsir dengan berbagai macam metode dan coraknya, menjadi salah satu usaha dari para ulama menjelaskan maskud dan kandungan yang dimiliki Al-Qur'an agar kehidayahannya dapat dijangkau. Tafsir memiliki kedudukan yang sangat strategis dan peran yang sangat siginifikan. Signifikansi tersebut ditunjukkan tafsir dengan melakukan gerakan-gerakan penafsiran (exegesist) terhadap ayat-ayat Al-Qur'an.

\section{B. Al-Qur'an dan Ke-hidayah-annya}

Satu hadits nabi dijelaskan bahwa Al-Qur'an merupakan ma'dubatullâh (hidangan Allah), hidangan ini membantu manusia untuk memperdalam pemahaman dan penghayatan tentang ajaran-ajaran Islam dan merupakan pelita bagi ummat Islam dalam menghadapi berbagai jenis persoalan hidup yang silih berganti seiring dan seirama perputaran waktu. ${ }^{15}$ Dalam upaya memahami ${ }^{16}$ 'hidangan' yang ditawarkan, maka diperlukan suatu ilmu yang bisa mengantarkan kewilayah pemahaman terhadap makna-makna yang terkandung didalamnya, dalam hal ini ilmu

${ }^{15} \mathrm{M}$ Quraish Shihab, Tafsir al-Misbâh, Pesan, Kesan dan Keserasian Al-Qur'an, (Lentera Hati, Jakarta: 2005), cet. ke-3, hal. V. vol. 1.

${ }^{16}$ Pada dasarnya upaya untuk memahami dan menafsirkan Al-Qur'an itu telah berjalan sejak generasi pertama Islam, bahkan dapat dikatakan Nabi Muhammad saw. sendiri sampai tahap tertentu juga melakukan upaya yang serupa, meskipun setiap muslim yakin bahwa ia tidak mungkin salah dalam memahami atau menafsirkan. Karena Allah Swt selalu mengontrol pikiran dan perkataannya. Lihat. Fakhruddin Faiz. Dalam, Hermeneutika Qur'ani, Antara Teks, Konteks, dan Kontekstualisasi, (Qalam, Yogyakarta: 2003), cet. ke-3, hal. 5. tafsir $^{17}$ berikut metode penafsiran AlQur'an ${ }^{18}$ berperan besar untuk mewujudkan hal itu.

Semangat gerakkan tafsir dalam dunia Islam mengalami perkembangan yang sangat menggembirakan, terbukti berkembangnya metode dan juga dibarengi dengan corak penafsirannya. Disebabkan dinamisasi antara teks dengan konteks aktifitas penafsiran menemukan perkembangannya dan bahkan pada tingkat perubahan, terutama sejak bergulirnya angin kemodernan di berbagai belahan dunia Islam. ${ }^{19}$ Frye, seperti yang dikutip

\footnotetext{
${ }^{17}$ Para ulama tafsîr diantaranya Muhammad ibn 'Abd al-'Azhim al-Zarqani dan T.M. Hasbi Ash-Shiddieqy (1322-1395 H/1904-1975 M) menyimpulkan bahwa kunci utama untuk memperdalam perbendaharaan Al-Qur'an ialah ilmu tafsir. Karena tanpa tafsir, Al-Qur'an mustahil bisa dipahami secara utuh dan menyeluruh; dan tanpa ilmu tafsir, Al-Qur'an tidak mungkin bisa disosialisasikan di tengah-tengah masyarakat luas. Lihat. Muhammad Amin Summa, dalam, Studi Ilmu-ilmu Al-Qur'an (Pustaka Firdaus, Jakarta: 2001), jil. 2, cet. ke-1, hal. 4,

${ }^{18}$ Dilihat dari segi usianya, penafsiran AlQur'an termasuk yang paling tua dibandingkan dengan kegiatan ilmiah lainnya dalam Islam. Pada saat Al-Qur'an diturunkan dalam upaya membimbing umat manusia menuju ibah kepada Yang Esa, melaksanakan perintahnya dan menjawab pertanyaan zaman di mana Al-Qur'an berinteraksi dengannya sejak lima belas abad yang lalu, Rasulullah saw. yang berfungsi sebagai mubayyin (penjelas) telah menjelaskan arti dan kandungan Al-Qur'an kepada sahabat-sahabatnya, khususnya menyangkut ayat-ayat yang tidak dipahami atau sama artinya. Keadaan seperti ini berlangsung sampai dengan wafatnya Rasulullah saw., walaupun harus diakui bahwa penjelasanpenjelasan tersebut tidak semua kita ketahui, sebagai akibat dari tidak sampainya riwayat-riwayat tentangnya atau karena memang Rasul saw. sendiri tidak menjelaskan semua kandungan Al-Qur'an. Lihat Abuddin Nata, dalam, Metodologi Studi Islam, (Rajawali Press, Jakarta: 2001), cet. ke-6, hal. 163-154.

${ }^{19}$ Sejatinya keberadaan tafsir harus mengalami perkembangan jaman bahkan perubahan. Hal ini karena konsekuensi logis dari
} 
oleh Ayman A. El-Desouky menyebut di awal-awal tahun 1970-an mengakui bahwa seseorang yang ingin mencoba mempelajari literature-literatur Islam secara serius diharuskan memulai studinya dengan Al-Qur'an hal ini dikarenakan kedudukannya yang sangat strategis dengan peran sebagai sebuah literartur. ${ }^{20}$

Kebutuhan akan ilmu tafsir menjadi sebuah hal yang utama, bahkan M. Abduh menyampaikan bahwa penulisan tafsir AlManaar dimotivasi oleh keinginan masyarakat akan kebutuhan pemahaman Al-Qur'an yang lebih komprenhensif. ${ }^{21}$ Karena ilmu tafsir berfungsi sebagai kunci utama untuk memahami Al-Qur'an dari berbagai aspeknya. Tanpa ilmu ini, tentu dalam konteksnya yang sangat luas, mustahil Al-Qur'an bisa dipahami dengan benar dan baik, setiap orang-khususnya mufassir-akan mengerti maksud kandungan Al-Qur'an, dengan demikian ia akan menjadi pelita dalam kehidupannya.

Penafsiran sebenarnya sudah dilakukan oleh nabi Muhammad saw., sebagai pembawa risalah dan pemangku nubuwwah dari Allah swt. Karena secara otoritatif memiliki peran menjelaskan AlQur'an. Di samping nabi Muhammad saw.,

diktum yang dianut oleh umat Islam bahwa AlQur'an itu shâlih li kulli zamân wa makân 'relevan untuk kapan dan dimanapun Al-Qur'an berjumpa dan menjumpai konteks yang beragam'. Lihat pengantar M. Amin Abdullah, dalam Abdul Mustaqim, Madzahibut Tafsîr: Peta Metodologi Penafsiran Al-Qur'an Periode Klasik Hingga Kontemporer, (Nun Pustaka, Yogyakarta: 2003), hal. xi.

${ }^{20}$ Ayman A. El-Desouky, Between Hermenutics Provenance and Textuality: The Qur'an and the questions of Methode in Approaches to World Literature, (SOAS University of London), h. 14. Diunggah tanggal 24 Juli 2018 Pukul. 10:30 WIB.

${ }^{21}$ Muhammad Abduh, Tafsir Al-Qur'an alHakim, (Kairo: Dar Al-Manaar, 1947), jil. I, cet. keI, h. 4-6. sebagai penafsir pertama dan utama, ada sahabat nabi Muhammad saw. yang juga melakukan hal yang sama dalam menjelaskan dan menafsirkan Al-Qur'an, seperti Abdullah ibn Abbas r.a. hingga kepada masa modern seperti yang diwakili oleh Muhammad Abduh dengan menulis kitab Tafsir Al-Manaar.

\section{Al-Qur'an dan Tafsir}

Sebagai kitab suci, Al-Qur'an memiliki dua dimensi, das sollen dan das sein, ${ }^{22}$ ia pasti memiliki nilai-nilai kebenaran secara tetap, abadi dan mutlak dan juga sebagai akibat dari produk dialogis yang terjadi dan terrelasikan antara wahyu dengan realitas sosial sebagai basis tujuannya. ${ }^{23}$ Sehingga Al-Qur'an hadir bukan dihadapkan ruang dan tempat yang tak berpenghuni, namun ia membangun dialogis yang terus berlangsung dengan relaitas sosial hingga masa pewahyuan selesai. Oleh sebab terjadinya dialogis, maka pemahaman teksteks yang disampaikan Al-Qur'an membutuhkan upaya pemahaman dan penggalian makna yang disampaikan Tuhan-Sebagai Pemiliki Kalam- sehingga maksud yang dikehendaki dapat terwujud dan pada gilirannya mampu memberikan petunjuk kepada pembacanya.

Tafsir sebagai akibat dari teks pertama, Al-Qur'an, sejatinya menjalankan tugas menjelaskan (al-syarh wa al-idhah) serta mengungkapkan (al-kasyf) makna dan maksud yang dikandung Al-Qur'an. Ia menjadi solusi atas permasalahan dalam memahami teks pertama (Al-Qur'an). Muhammad Husain Adz-Dzahabi

\footnotetext{
${ }^{22}$ Halid Al-Kaf, Quo Vadis Liberalisme Islam Indonesia, (Jakarta: Kompas, 2011), cet. ke-I, h.34.

${ }^{23}$ Halid Al-Kaf, Quo Vadis Liberalisme..., h. 34.
} 
menyatakan bahwa tafsir sebagai pengetahuan yang didalamnya dibahassesuai dengan kadar kemampuan manusiamaksud-maksud Allah swt. yang terkandung dalam Al-Qur'an, ia menjadi disiplin yang bias mencakup pengetahuan pemahaman akan makna dan penjelasan dari maksud Allah swt. $^{24}$ seiring berjalannya waktu, kajian tentang AlQur'an $^{25}$ dan kemudian tafsir sebagai teks

\footnotetext{
${ }^{24}$ Muhammad Husain Adz-Dzahabi, AlTafsir wa al-Mufassirun, Kairo: Mathba'ah Musthafa Al-Halabi, 1976, cet. ke-2, hal. 20.

${ }^{25}$ Perkembangan yang mengkhususkan tentang studi Al-Qur'an-tidak termasuk ke dalam studi tafsir- tergolong kepada beberapa kategori masa pertumbuhan studi tentang Al-Qur'an, mulai dari abad ke I dan ke II hijriah, di mana pada masa ini terjadi di masa nabi Muhammad saw. dan generasi-generasi awal, yakni para sahabat. Pada masa ini studi tentang ilmu al-Qur'an belum ditemukan tanda-tanda akan kehadirannya. Hal itu karena pada generasi awal Islam ini adalah mereka yang menggunakan Bahasa komunikasi dengan menggunakan Bahasa Arab-bahasa yang dipakai oleh Al-Qur'an untuk mengkodifikasi kalam Tuhan- dan bila terjadi persoalan dan permasalahan yang muncul, tidak lagi menunggu lama melainkan para sahabat menanyakan langsung kepada sumbernya (baca: nabi Muhammad saw.). Karena faktor dekatnya dengan peristiwa-peristiwa wahyu dan kerisalahan para peneliti menganggap studi tentang al-Qur'an belum dijumpai pada generasi ini. Periode berikutnya adalah abad ke-III dan keIV H. pada abad ini dipandang sebagai masa munculnya beberapa hasil kajian tentang al-Qur'an dan memunculkan beberapa kitab, seperti Ilmu Asbab al-Nuzul, karya Aki bin Al-Madini (w. 234 H.), An-Nasikh wa al-Mansukh dan Ilmu Qira'at dan Fadhail al-Qur'an, karya Abu Ubaid al-Qasim bin Salam (w. 224 H.), Ilmu al-Makky wa alMadani, karya Muhammad bin Ayyub Adh-Dhiris (w. 294 H.), Al-Hawi fi 'Ulum al-Qur'an (27 jilid), karya Muhammad bin Khalaf al-Marzuban (w. 309 H.) kitab-kitab ini muncul pada abad ke-III $\mathrm{H}$. Sedangkan yang terbit pada abad ke-IV H. di antaranya: Ilmju Gharib al-Qur'an, karya Abu Bakar As-Sijistani (w. 330 H.), Ajaib 'Ulum alQur'an, karya Abu Bakar Muhammad bin AlQasim Al-Anbari (w. 328 H.), Al-Mukhtazan fi 'Ulum al-Qur'an, karya Abu al-Hasan al-Asy'ari (w. 324 H.), Nakat al-Qur'an al-Dilatu 'ala al-
}

berikutnya mengalami perkembangan yang cukup panjang.

Sebagai sebuah gerakan mulia, eksistensi tafsir sangat dibutuhkan oleh setiap pengikut yang ingin memahami AlQur'an. Karena satu sisi tafsir sangat membantu seseorang yang memang belum mengenal dan memahami Al-Qur'an. Banyak pakar dan sarjana muslim yang menyatakan bahwa aktifitas penafsiran memiliki peran penting dalam rangka

Bayani fi Anwa' al-'Ulum wa al-Ahkam alMambiati 'an Ilhtilafi al-Anami, karya Abu Muhammad al-Qassab Muhammad bin Ali AlKarakhi. Al-Istighna fi 'ulum al-Qur'an, karya Muhammad bin Ali al-Adawi ( w. 388 H.). Berikutnya adalah perkembangan studi al-Qur'an pada abad ke V dan VI H. pada masa ini muncul beberapa karya di antaranya; Ilmu I'rab al-Qur'an, Al-Burhan fi 'Ulum al-Qur'an (30 jilid), karya Ali bin Ibrahim bin Said al-Khufy (w. 430 H.), AlTafsir fi al-Qira'at al-Sab'i dan al-Muhkam fi alNuqath, karya Abu Amr al-Dani (w. 444 H. Sedangkan abad ke-VI munculnya kitab-kitab yang membahas tentang ilmu mubhamat al-Qur'an yakni; Mubhamat al-Qur'an, karya Abu al-Qasim Abd al-Rahman nin Ahmad al-Suhaly (w. 581 H.), Funun Afham fi 'Ajaib al-Qur'an dan Al-Mujtaba fi 'Ulum Tata'alluq bi al-Qur'an karya Ibnu Al-Jauzy (w. 597 H.). Abad berikutnya, yakni abad ke-VII dan ke VIII yang hadir adalah al-Qira'at, karya Alam al-Din Al-Sakhawy (w. 634 H.), Al-Mursyid al-Wajiz fi Maa Yata'allaqu bi Al-Qur'an, karya Abu Syamah (w. 655 H.), Ilmu Majaz al-Qur'an, karya Ibnu Abd al-Salam atau yang popular dengan nama Al-'Izz (w. 660 H.) dan pada abad ke-VIII H. tertulis kitab Ilmu Bada'i al-Qur'an, karya Ibnu Abi al-Ishba', Ilmu Amtsal al-Qur'an karya Abu alHasan Al-Mawardi, Ilmu Hujaj al-Qur'an, karya Nam al-Din al-Thufy (w. 716 H.), Ilmu 'Aqam alQur'an, karya Ibnu al-Qayyim (w. 752 H.), AlBurhan fi 'Ulum Al-Qur'an (empat jilid), Badr alDin al-Zarkasy (w. 794 H.) perkembangan studi AlQur'an dan berakibat pada munculnya penulisanpenulisan yang menuliskan studi tentangnya berlanjut hingga kepada abad ke IV $H$. yang di dalamnya juga mencantumkan Muhammad Rasyid Ridla dan Muhammad Abduh sebagai salah satu tokoh yang ikut andil mengembangkan studi tentang al-Qur'an. Lihat. Dr. Hamdani Anwar, Pengantar Ilmu Tafsir, Jakarta: Penerbit Fikahati, 1995, cet. ke-I, hal. 13-21. 
menjelaskan kehdiayahan Al-Qur'an sebut saja Iffat Syarqawi, seorang pakar tafsir dan ilmu Al-Qur'an menyatakan bahwa tafsir itu sebagai aktifitas budaya yang dikonstruksiakan di atas pemahaman terhadap teks suci dalam bentuknya yang kronologis ataupun yang tematis. Di sini Iffat Syarqawi mendudukan tafsir sesuatu yang tidak lepas dari relasi teks-budaya yang keduanya saling bertautan dalam membentuk teks dan memproduksi makna tafsir. Menurutnya juga bahwa urgensi tafsir itu dapat dilihat dari; pertama, problem makna teks yang tidak dapat dipecahkan, kedua, uraian yang tidak memadai, ketiga, terdapat kontradiksi internal teks, keempat, terdapat makna teks yang tidak dapat diterima, dan, kelima, adanya pemeluk Islam yang tidak dapat mengerti bahasa Arab, dapat dikatakan bahwa kehadiran tafsir itu adalah untuk mempermudah pemahaman terhadap teks. $^{26}$

Pada tataran aksiologis tafsir itu tidak hanya memiliki kepentingan teoritis, yaitu memperjelas makna kata-kata dan pemahaman teks Al-Qur'an yang diadaptasikan dengan situasi historis penafsir, tetapi ia juga memiliki manfaat praktis, yaitu agar teks ayat itu benar-benar memiliki arti fungsional bagi prilaku para penganutnya. Menafsirkan ${ }^{27}$ adalah usaha untuk bisa memahami maksud Al-Qur'an, bahkan menurut al-Ashfahany

${ }^{26}$ Iffat Muhammad Syarqawi, Ittijahat al-

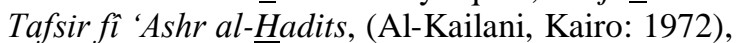
hal. 182.

${ }^{27}$ Abdullah Saeed menyebutkan setidaknya dalam tradisi-tradisi tafsir memiliki empat pendekatan; pendekatan berbasis linguistic, pendekatan berbasis logika, pendekatan berbasis tasawuf dan pendekatan berbasis riwayat. Lihat Abdullah Saeed, Al-Qur'an Abad 21, Tafsir Kontekstual, terj. Ervan Nurtawab, (Bandung: Mizan, 20116), cet. ke-I, h. 30. mengatakan, bahwa karya termulia dan usaha manusia yang terpuji adalah menafsirkan Al-Qur'an serta menakwilkannya. ${ }^{28}$ Hal ini dikarenakan objek $^{29}$ yang ditekuninya. ia merupakan aktifitas intelektual yang membutuhkan seperangkat disiplin keilmuan khusus. Seperangkat keilmuan tersebut diperlukan dalam rangka menemukan keakuratan dalam penafsiran Al-Qur'an. Oleh karena itu, seseorang yang menafsirkan Al-Qur'an tanpa memiliki seperangkat ilmu khusus tersebut, secara keilmuan dianggap tidak mempunyai kapasitas untuk melakukan gerakan penafsiran (exegesist).

Seorang penafsir Al-Qur'an menghadapi tugas yang berat dan sangat penting yang bersifat ilmiah. Hal ini dikarenakan objek yang ia tekuni adalah Al-Qur'an yang merupakan verbum dei, 'kalamullâh'. Pada dasarnya tingkat pengetahuan yang dimiliki oleh setiap ulama tafsir umumnya tidak seberapa jauh bahkan dapat dikatakan sama. ${ }^{30}$ Pada dasarnya perbedaan hanya terletak pada kemampuan mereka mengungkapkan pengertian ayat-ayat yang bersifat rahasia, samar dan tersembunyi di balik kata-kata dan kalimat, hal yang demikian itulah yang membuat mereka berbeda pendapat dan berselisih dalam menafsirkan ayat demi ayat yang terdapat dalam Al-Qur'an. ${ }^{31}$

Kejumudan yang terjadi di sebagian para pendakwah- telah sampai kepada tingkatan keengganan (baca: mencegah)

${ }^{28}$ Ahmad Syurbasy, Sejarah Perkembangan Tafsir Al-Qr'an al-Karim, (Kalam Mulia, Jakarta: 1999), cet. ke-1, hal. 19.

${ }^{29}$ Objek dari materi penafsiran adalah AlQur'an yang memiliki kedudukan mulia. Hal ini bisa kit saksikan dalam mukaddimah tafsir imam al-Thabârî dan juga ungkapan yang pernah disampaikan oleh Al-Zarkasyî, Ibid.

${ }^{30}$ Ibid, hal. 29.

${ }^{31}$ Ibid. 
mengambil hujjah yang bersumber dari AlQur'an dan al-sunnah, baik itu dalam masalah-masalah dunia maupun agama. Bahkan pada tingkat selanjutnya mereka merasa sudah cukup dengan-hanya bersumber- kitab-kitab fiqh, padahal di dalamnya masih menyimpan banyak problematika dan polemik di kalangannya. Sehingga pada gilirannya setiap perkataan yang muncul dari seorang faqîh-dikalangan mereka-menjadi satu-satunya hujjah dan sanad yang kebenarannya masih dianggap absolute, muthlak. Permasalahan seperti ini mengantarkan Al-Qasimi menciptakan situasi yang dapat membuat ia menjadikan Al-Qur'an dan al-Sunnah shahih sebagai pijakan utama dalam segala hal. Kaidah dalam penafsiran dikemukakan Muhammad Jamal al-Din al-Qasimi menjelaskan kaidah-kaidah penafsiran yang beliau simpan pada juz pertama, hal itu dilakukan agar seorang pembaca sebelum membaca tafsirnya terlebih dahulu dapat memahami aturan-aturan yang menjadi dasar sebuah penafsiran.

Adapun tingkatan-tingkatan para mufassir yang terbaik adalah para sahabat. Karena mereka terbukti dipuji, baik dalam Al-Qur'an maupun al-Sunnah, dan karena Al-Qur'anpun diturunkan dengan medio bahasa mereka, kesalahanpun sangat jauh dari mereka, karena mereka selalu bertanya kepada rasul saw. mengenai masalah yang menyulitkan mereka. ${ }^{32}$ Dan tafsir yang sangat populer di kalangan sahabat adalah tafsir Ibnu 'Abbas. Muhammad Abduh menjelaskan bahwa sesungguhnya inti dari sebuah kerja penafsiran adalah menekankan fungsi-fungsi kehidayahankarena sesungguhnya Al-Qur'an mentahbiskan dirinya sebagai "hudaan"

\footnotetext{
${ }^{32}$ Muhammad Jamal al-Din al-Qasimi, Tafsir Mahasin..., juz 1 hal. 13
}

petunjuk bagi orang-orang yang bertaqwa maupun bagi semua manusia- sehingga bila fungsi-fungsi itu dapat ditemukan oleh manusia (melalui tafsir tentunya) ia akan mampu menjalankan kehidupan dengan benar dan tentunya dapat disetujui oleh alQur'an. ${ }^{33}$

\section{Hermeneutika, Tawaran \\ Metodologis Menafsirkan Al-Qur'an}

Term hermeneutika merupakan bahasan yang ada dalam pembahasan dan kajian bahasa. Komaruddin Hidayat $^{34}$ menyebut bahwa term hermeneutika muncul sebagai akibat dari proses morfologis derivatif dan juga disinyalir dikenal dari motologi yang berkembang di Yunani, dan dia dikenal dengan Hermes, seorang dewa yang berperan dan dibekali tugas sebagai penghubung antara Sang Maha Dewa yang bersifat transenden dan para manusia yang berada di bumi.

Secara umum terminologi hermeneutika dapat didefinisikan sebagai teori atau filsafat tentang interpretasi makna. ${ }^{35}$ Sayyed Hossein Nasr menyebut bahwa Hermes merupakan sosok yang dikenal dengan nabi Idris AS. Hipotesis ini didasari mengingat ia diyakini sebagai manusia pertama yang mengetahui seni tulis-menulis, teknologi tenun, kedokteran, astrologi dan lain-lain. ${ }^{36}$ Kepandaian Hermes dalam aktifitas menenun atau

\footnotetext{
${ }^{33}$ M. Quraish Shihab, Studi Kritis Tafsir AlManar, Karya Muhammad Abduh dan Muhammad Rasyid Ridha, Bandung: Pustaka Hidayah, 1994, cet. Ke-I, hal. 68 .

${ }^{34}$ Komaruddin Hidayat, Memahami Bahasa Agama, Sebuah Kajian Hermeneutik, (Jakarta: Paramadina1996), cet. ke-I, h. 13.

${ }^{35}$ Lihat. Ahmala, Lahirnya Hermeneutika, dalam "Hermeneutika Transendental, editor Nafisul 'Atho' dab Arif Fahrudin, (Jogjakarta: Ircisod, 2003), cet. ke-I, h. 15.

${ }^{36}$ Ahmala, Lahirnya Hermeneutika, dalam "Hermeneutika Transendental, h. 15.
} 
memintal dalam konteks hermeneutika, karena kata kerja "memintal" disebutkan oleh Komaruddin Hidayat dengan mengutip pendapat Vincent Crapanzano, memiliki padanan yang sama tegere, kata yang berasal dari bahasa Latin. Produk yang dihasilkannya disebut dengfan textus atau text. ${ }^{37}$ Zygmunt Bauman menyebutkan bahwa hermeneutika sebagai upaya menjelaskan dan menelusuri pesan dan pengertian dasar dari sebuah ucapan atau tulisan yang tidak jelas, kabur, remangremang dan kontradiksi, sehingga menimbulkan keraguan dan kebingungan bagi pendengar dan pembaca. ${ }^{38}$

Persoalan yang sangat penting dan mengharuskan ditemukan jalan keluarnya adalah bagaimana Hermes atau juga bisa disebut nabi Idris AS. menafsirkan pesan Tuhan yang menyampaikannya dengan instrument bahasa langit tetapi pada satu sisi, firman Tuhan dapat bisa dipahami oleh manusia-sebagai objek firmansehingga manusia mampu memahami sesuai dengan bahasa yang mereka gunakan. Sehingga tujuan-Nya menyampaikan firman tersebut dapat tercapai karena terbangun dialogis yang tepat. Melihat peristiwa teks seperti itu, maka dari itu, hermeneutika dapat diartikan sebagai sebuah ilmu atau seni menginterpretasi "the art of interpretation". 39

Sebagai sebuah seni menafsirkan, perkembangan hermeneutika mengalami perkembangan yang sangat signifikan, bahkan mengalami kemajuan yang terjadi pada abad ke-16. Karena pada abad ini

${ }^{37}$ Komaruddin Hidayat, Memahami Bahasa Agama, Sebuah Kajian Hermeneutik..., cet. ke-I, h. 126.

\footnotetext{
${ }^{38}$ Komaruddin Hidayat, Memahami Bahasa Agama, Sebuah Kajian Hermeneutik..., h. 126.

${ }^{39}$ Ahmala, Lahirnya Hermeneutika, dalam "Hermeneutika Transendental, h. 15.
}

hermeneutika terjadi diskursus di kalangan akademisi berkenaan dengan otensitias Bibel. Diskursus yang terjadi guna menghasilkan penjelasan mengenai kejelasan serta pemahaman yang benar mengenai kandungan Bibel yang dalam berbagai hal dianggap bertentangan. ${ }^{40}$

Hermeneutika yang berkembang di Barat pada awalnya bagian dari studi Filologi, ilmu yang berkaitan teks kuno ini membahas mengenai asal-usul teks. ${ }^{41}$ Hermeneutika sebagai sebuah aktifitas penafsiran tentunya sangat bersinggungan dengan sejarah teks. Karenanya keterkaitannya dengan bahasa menjadi sebuah keharusan, karena bagaimana pun segenap rangkaian aktifitas manusia, baik dalam ucapan, menulis berpikir dan menginterpretasikan selalu berkaitan dengan bahasa. ${ }^{42}$

Teks merupakan fiksasi atau pelembagaan suatu rangkaian kejadian wacana lisan dalam bentuk tulisan. ${ }^{43}$ Bahkan teks lebih luas dari sebuah realitas. Bahkan J. Derrida, seperti yang dikutip Ahmala menyatakan bahwa, "everything text and there is nothing beyond the text". ${ }^{44}$ Karena ia berkaitan dengan pemahaman "verstehen", peran hermeneutika diakui sangatt relevan untuk diterapkan dalam ilmu-ilmu kemanusiaan. Sebagai bagian dari metode verstehen, tugas pokok dari hermeneutika adalah bagaimana ia

\footnotetext{
${ }^{40}$ Komaruddin Hidayat, Memahami Bahasa Agama, Sebuah Kajian Hermeneutik.., h. 127.

${ }^{41}$ Komaruddin Hidayat, Menafsirkan Kehendak Tuhan, (Bandung: Teraju, 2004), cet. keII, h.139.

${ }^{42}$ Ahmala, Lahirnya Hermeneutika, dalam Hermeneutika Transendental, Nafsiul 'Atho' dan Arif Fahrudin, (Yogyakarta: Ircisod, 2003), cet. keI, h. 15 .

${ }^{43}$ Komaruddin Hidayat, Menafsirkan Kehendak Tuhan, ...h. 142.

${ }^{44}$ Ahmala, Lahirnya Hermeneutika, dalam Hermeneutika Transendental..., h. 16.
} 
menafsirkan sebuah teks klasik atau realitas sosial di masa lalu dan dinilai asing agar mampu menjadi milik orang yang hidup di masa, tempat dan suasana dan kultural yang berbeda. ${ }^{45}$

Tradisi diskursus yang dibangun atas kritis pemikir-pemikir Kristen berdampak pada tradisi keilmuan Al-Qur'an yang dikembangkan oleh para sarjana muslim. Mereka berusaha mencari formulasi yang tepat dan sesuai agar kontinyuitas pesanpesan Al-Qur'an dapat juga berdialog dengan masyarakat yang dijumpainya meskipun sudah melintasi beberapa masa pewahyuan. Kritik yang dimulai dan dikembangkan oleh para pemikri muslim modern memunculkan diskursus baru yang berdampak pada kesimpulan-kesimpulan yang memerlukan adanya model baru dalam penafsiran. Melihat berbagai kekurangan yang diamati, Hassan Hanafi ${ }^{46}$ seperti yang telah dikutip Ilham B. Saenong, berusaha menawarkan model dan metode penafsiran baru yang kemudian ia sebut dengan hermeneutika sosial (al-

\footnotetext{
${ }^{45}$ Ilyas Supena, Rudolf Bultman, Hermeneutika Teologis Rudolf Bultman, dalam Hermeneutika Transendental, editor, Nafisul 'Atho dan Arif Fahrudin, (Yogyakarta: Ircisod, 2003), cet. ke-I, h. 95.

46 Pemikir Mesir kontemporer ini sangat terkenal dengan tulisan yang kemudian diharapkan menjadi sebuah gerakkan. Tulisannya memang sempat memperoleh tempat diskursus di kalangan para sarjana muslim di Mesir mengingat penggunaan istilah Kiri Islam yang oleh kebanyakan kaum muslim, kata kiri selalu diasosiasikan dengan sesuatu yang negatif. Riwayat akademisnya terpengaruhi oleh pemikir barat ketika ia menimba ilmu di negeri tetangga, Perancis, tepatnya di Universitas Sorbone, di antara pemikir barat yang menjadi gurunya adalah Jeen Gitton, Paul Riccour. Husserl dan MAsnion. Lihat. Abdul Haris Rasyidi dalam. Kajian Islamologi tentang Tradisi Pembaharuan dan Modernitas. Telaah Buku Dirasaat Islamiyyah Hassan Hanafi, Jurnal Islam Nusantara, Vol. 1. No. 2 edisi. Juli-Desember 2017, h. 206.
}

Manaj al-Ijtima' fi al-Tafsir). ${ }^{47}$ Bentuk penafsiran baru menurut Muhammad Shahrur seperti yang dikutip Kurdi dkk., adalah di antaranya seseorang tidak mesti harus terkungkung dengan produk penafsiran klasik, hal itu mengingat tafsir tidak lepas dari ruang dan waktu di mana tafsir itu ditulis. ${ }^{48}$

Hassan Hanafi, selanjutnya disebut Hanafi, merupakan pemikir muslim dengan latar belakang akademis Doktor di bidang filsafat di universitas Kairo dan merupakan alumni dari Universitas Sorbone Perancis. ${ }^{49}$ Hanafi, ${ }^{50}$ berusaha menyusun aktifitas tafsir ke dalam beberapa karakteristik, tafsir juz'i, tafsir maudlu'i, tafsir zamani, tafsir al-waqi'i, berorientasi pada makna tertentu dan tidak kepada memperbincangkan hal yang bersifat teoritik, bersifat eksperimental dan memperhatikan problem kontemporer. Salah satu pemikiran Hanafi yang ia kembangkan terdapat dalam kitab Dirasah Islamiyyah, perlu diadakannya rekonstruksi ilmu teologi Islam, baginya teologi Islam klasik perku dilakukan perubahan orientasi perangkat konseptual sistem kepercayaan yang sesuai dengan perubahan konteks sosial politik yang terjadi. Kritisk ia adalah karena ilmu teologi Islam klasik muncul dan bertalian dengan konteks sejarah ketika inti sistem

\footnotetext{
${ }^{47}$ Ilham B. Saenong, Hermeneutika Pembebasan, Metodologi Tafsir Al-Qur'an Menurut Hassan Hanafi, (Bandung: Teraju, 2002), cet. ke-I, 142.

${ }^{48}$ Kurdi, dkk., Hermeneutika al-Qur'an dan Al-Hadits, (Yogyakarta: Elsaq Press, 2010), cet. keI, h. 296.

${ }^{49}$ Devi Muharrom Sholahudin, Studi Metodologi Tafsir Hassan Hanafi, Jurnal Studia Qur'anika, Vol. 14. No. 1, Maret, 2016.

${ }^{50}$ Mashud Sasaki, Tafsir Hermeneutika AlQur'an Perspektif Hassan Hanafi, http//hudcentre. Wordpress. Diunggah tanggal 1 Agustus 2018 pukul 11:00 WIB.
} 
keislaman sistem kepercayaan berada pada pusat transendensi Tuhan, sejarah mencatat konsep teologi keislaman klasik ini menemukan ujiannya di saat diserang oleh beberapa faksi dan sekte-sekte dan tradisi lama. Sehingga teologi dengan model ini dihadirkan guna mempertahankan doktrin utama dan untuk memelihara kemurniannya. $^{51}$

Bagi Hanafi, berinteraksi dengan turast, dapat dibagi kepada turats al-qadim (teks lama), turats al-gharib al-waqi' (realita ). ${ }^{52}$ Hasil karya Qadhaya Mu'ashirat fi Fikrina al-Mu'ashir dan Qadhaya Mua'ashirat fi al-Fikr al-Gharb dijadikan sebagai sumber yang membekali Hanafi dalam menjelaskan pemikirannya yang terdapat dalam dua buah karyanya yang dikenal dengan judul al-turats alTajdid (tradisi dan pembaruan) dan Istighrab (Oksidentalis). ${ }^{53}$

Proyek pengembangan hermeneutika yang dikembangkan Hanafi menggunakan fenomenologi yang diadopsinya dari teori fenomenologi Edmund Husserl. ${ }^{54}$ Lebih lanjut ia menegaskan, ada beberapa tahapan yang mesti ditempuh oleh seorang mufassir bila ingin melakukan aktifitas penafsiran, pertama, wahyu dapat

${ }^{51}$ Abdul Haris Rasyidi dalam. Kajian Islamologi tentang Tradisi Pembaharuan dan Modernitas. Telaah Buku Dirasaat Islamiyyah Hassan Hanafi, Jurnal Islam Nusantara, Vol. 1. No. 2 edisi. Juli-Desember 2017, h. 211.

${ }^{52}$ Abdul Haris Rasyidi dalam. Kajian Islamologi tentang Tradisi Pembaharuan dan Modernitas. Telaah Buku Dirasaat Islamiyyah Hassan Hanafi, Jurnal Islam Nusantara, Vol. 1. No. 2 edisi. Juli-Desember 2017, h. 211

${ }^{53}$ Abdul Haris Rasyidi dalam. Kajian Islamologi tentang Tradisi Pembaharuan dan Modernitas. Telaah Buku Dirasaat Islamiyyah Hassan Hanafi, Jurnal Islam Nusantara, Vol. 1. No. 2 edisi. Juli-Desember 2017, h. 211

${ }^{54}$ Devi Muharrom Sholahudin, Studi Metodologi Tafsir Hassan Hanafi, Jurnal Studia Qur'anika, Vol. 14. No. 1, Maret, 2016. h. 57 diletakkan dalam "tanda kurung" (epoche), yakni "menunda putusan", pada posisi ini, seorang mufassir tidak melakukan afirmasi dan tidak pula menolak. Kedua, Al-Qur'an diterima sebagaimana layaknya teks-teks lain, seperti karya sastra, teks filosofis, dokumen sejarah dan sebagainya. Karena ia memiliki posisi yang sama, maka perlakuan teks Al-Qur'an maka ia dapat ditafsirkan berdasarkan aturan yang sama. Ketiga, tidak ada penafsiran palsu atau benar, pemahaman benar atau salah. Keempat, tidak ada penafsiran tunggalterhadap teks, dan kelima, konflik penafsiran merefleksikan konflik sosiopolitik dan bukan konflik teoritis, karena itu produk penafsiran merepresentasikan sosio-politik penafsir. ${ }^{55}$ Dengan teori hermeneutika yang dikembangkan, Hanafi menggunakan metode hermeneutika sebagai alternatif metode interpretasi teks atas kritiknya pada metode tafsir klasik.

Sedangkan Muhammad Shahrur, selanjutnya disebut Shahrur, dengan karyanya yang cukup fenomenal, $A l$ Qur'an wa al-Kitab Qira'ah alMu'ashirah, yang dapat diterjemahkan dengan "Al-Qur'an dan Al-Kitab, Sebuah Pembacaan Kontemporer". ${ }^{56}$ Memberikan satu contoh penafsiran modern dengan berusaha melakukan pembacaan secara kontekstual. Di samping itu pula, ia mengembangkan teori limitasi dan menolak sinonim dalam bahasa Arab, juga dalam Al-Qur'an. Proyek hermeneutika yang dikembangkan Shahrur terbagi pada tiga model;, kainunah (kondisi berada),

55 Devi Muharrom Sholahudin, Studi Metodologi Tafsir Hassan Hanafi, Jurnal Studia Qur'anika, Vol. 14. No. 1, Maret, 2016. h 58.

${ }^{56} \mathrm{Buku}$ ini sudah diterjemahkan dalam bahasa Indonesia dengan Judul "Hermeneutika AlQur'an, Sebuah Pembacaan Kontemporer yang diterjemahkan oleh Dr. Sahiran Syamsuddin dengan penerbit Elssaq Pres Yogyakarta. 
sairurah (kondisi berproses), dan shairurah (kondisi menjadi). ${ }^{57}$ Penolakan Shahrur terhadap bahasa yang dianggap bersinonim pernah dikembangkan oleh Ibnu Al-Faris, ${ }^{58}$ Ibnu Jinni dan beberapa sarjana muslim lain. Sedangkan teori limitasi yang dikembangkan oleh Shahrur dalam konteks memahami ayat-ayat muhkamat (ayat yang secara pasti dapat difahami) sesuai dengan konteks sosio historis masyarakat kontemporer, agar ajaran Al-Qur'an tetap relevan dan kontekstual sepanjang masih berada dalam wilayah batas hukum Allah. Swt. ${ }^{59}$

Salah satu bentuk keteguhan dalam mempertahankan asinonimisasi, Shahrur berusaha membedakan dalam menafsirkan kata-kata "Al-Kitab', Al-Dzikr dan "AlQur'an". Ia mengajukan satu pertanyaan dengan "apakah kata-kata tersebut di atas sebagai sebuah makna yang sama karena

\footnotetext{
${ }^{57}$ http//. Aeliftiya.blogspot.com. Olah Pikir, Hermeneutika Muhammad Syahrur, diunggah pada tanggal 1 Agustus 2018 pukul. 10:30 WIB.

${ }^{58} \mathrm{Abu}$ al-Husain Ahmad ibn Faris ibn Zakariya ibn Habib al-Razi, lahir pada tahun 329 H/941 M. Nasab dan tanah kelahirannya, sejauh ini, masih diperdebatkan. Ada yang berpendapat bahwa ia lahir di Quzwain. Pendapat ini tidak sepenuhnya benar, karena hanya didasarkan pada logat Quzwain yang pernah diucapkannya. Pendapat lain menyatakan bahwa ia berasal dari Rustaq al-Zahra', sebuah desa yang dikenal dengan sebutan Karsafah Wijyanabadz. al-Qifthi berpendapat bahwa Ibn Faris berasal dari Hamadzan, dan meninggal di Rayy, keduanya berada di Persia (Iran - Sekarang), lalu ia hijrah ke Quzwain kemudian ke Miyang. Yaqut al-Hawawi juga meriwayatkan bahwa ia juga pernah ke Baghdad untuk mempelajari hadits. Ibn Khillikan menyatakan bahwa ia menghabiskan sebagian besar masa hidupnya di Hamadzan. Biografi Ibnu Al-Faris dapat dilihat dalam Muhbib Abdul Wahab, dalam. Mengenal Pemikirann Linguistik Ibnu Faris (W. 329-395 H/941-1004 M.). www.fitk.uinjkt.ac.id. Diunggah pada tanggal 1 Agustus 2018 pukul. 11:35 WIB.

${ }^{59}$ http//. Aeliftiya.blogspot.com. Olah Pikir, Hermeneutika Muhammad Syahrur, diunggah pada tanggal 1 Agustus 2018 pukul. 10:30 WIB.
}

merupakan sinonim, atau lebih memiliki makna spesifik?. ${ }^{60}$ Dalam bukunya "AlKitab wa al-Qur'an, Qira'ah Mu'ashirah", Shahrur mencoba mendifferiensasi kata $\mathrm{Al}$ Qur'an dengan kata Al-Kitab, menurutnya term al-Kitab, merupakan bentuk derivasi $k a-t a-b a$, dalam tradisi linguistic Arab diterjemahkan dengan pengumpulan sesuatu dengan sesuatu yang lain untuk memperoleh manfaat atau untuk membentuk sebuah tema sempurna. ${ }^{61}$ Seperti dalam beberapa literatur keislaman, fiqh misalnya, sering disebutkan pembahasan tentang sesuatu dengan menggunakan kata kitab al-shaum, kitab al-shalah dan lain sebagainya. Kata ajektif dari ka-ta-ba dengan katib, dapat dimaknai seseorang yang mengumpulkan berbagai macam tema dan menyusun kalimat dan mengaitkan antara satu kejadian dengan kejadian yang lainnya yang terdokumentasikan dalam bentuk tulisan yang utuh. ${ }^{62}$ Karena itulah di saat Allah swt. memberikan wahyu kepada nabi Muhammad saw. berupa tema yang bermacam-macam, maka setiap tema dapat disebut sebagai kitab sebagaimana disebut dalam QS. Al-Bayyinah/98: 2-3.

Kata kutub al-qayyimah yang diungkapkan di sini menurut Shahrur mencakup pengertian kitab al-khalqi (kitab tentang penciptaan), kitab al-sa'ah (kitab tentang hari kiamat), kitab al-shalah (kitab tentang shalat). Dapat dipahami bahwa yang dimaksud dengan kitab adalah pernyataan yang terkandung di dalamnya, bukan kitab dalam pengertian teks atau

\footnotetext{
${ }^{60}$ Muhammad Shahrur, Prinsip dan Dasar Hermeneutika Kontemporer, terj. Sahiron Syamsuddin, (Yogyakarta: Elsaq Press, 2004), cet. ke-I, h. 65.

${ }^{61}$ Muhammad Shahrur, Prinsip dan Dasar Hermeneutika Kontem porer..., h. 66.

${ }^{62}$ Muhammad Shahrur, Prinsip dan Dasar Hermeneutika Kontemporer..., h. 66.
} 
tulisan semata-mata. ${ }^{63}$ Abi Bakar Jabir AlJazairi menegaskan jika, kata al-kutub dipahami sebagai kitab yang mencakup keseluruhan terhadap semua shuhuf, maka bagaimana membaca shuhufan muthaharah? Pertanyaan seperti ini dapat dipahami sebagai kitab yang tersusun dari shuhuf, jika ia banyak maka otomatis menjadi kitab, sedangkan Al-Qur'an merupakan kitab yang tersusun dari beberapa shuhuf. $^{64}$

Kaitan yang lain, ketika Allah swt. berfirman mengenai sebuah kitab yang mutasyabih dengan redaksi "kitaban mutasyabihan" seperti yang tercantum dalam QS. Al-Zumar/39: 23.

Bagi Shahrur, ayat ini dimaksudkan bahwa Allah swt. tidak bermaksud menyebut kandungan mushaf secara keseluruhan, tetapi ia sebatas kumpulan ayat-ayat mutasyabihat. Demikian di saat Allah swt. berfirman dalam QS. AliImran/3: 145 .

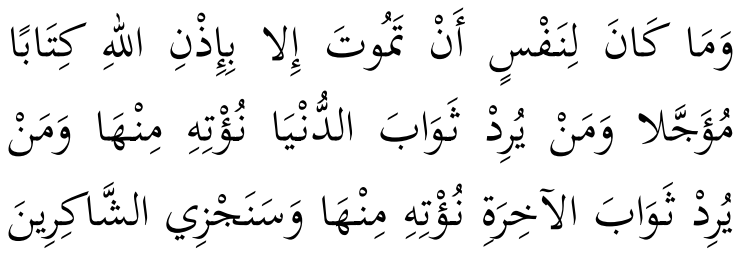

$(1 \leq 0)$

"Dan setiap yangbernyawa tidak akan mati kecuali dengan izin Allah, sebagai ketetapan yang telah ditentukan waktunya. Barangsiapa menghendaki pahala dunia, niscaya Kami berikan kepadanya pahala (dunia) itu, dan barangsiapa menghendaki pahala akhirat, Kami berikan (pula) kepadanya pahala (akhirat) itu, dan Kamiakanmemberikan balasan kepada orang-orang yangbersyukur"

\footnotetext{
${ }^{63}$ Muhammad Shahrur, Prinsip dan Dasar Hermeneutika Kontemporer..., h. 66.

${ }^{64}$ Abi Bakar Jabir Al-Jazairi, Aysar alTafasir, (Madinah: Maktabah al-'Ulum wa alHikam, 2003), jil. II, cet. ke-VI, h. 1487.
}

Pengertian kata $凶=\varnothing 凶 \bullet$ (1) है
sebagai kitab al-maut atau kumpulan
berbagai macam unsur yang yang apabila
berkumpul menyebabkan fenomena
kematian. $^{65}$ Berdasarkan
penjelasan di atas, Shahrur ${ }^{66}$ menegaskan: "Memaknai seluruh penggalam ayat yang terdapat dalam Al-Qur'am yang memuat kata kitab dengan dimaknai dengan 'sebuah kitab yang mencakup kandungan mushaf secara keseluruhan merupakan sebuah kesalahan besar'. Karena keseluruhan ayat-ayat sejak QS. Al-Fatihah sebagai surat pertama hingga QS al-Naas yang menjadi surat terakhir terdiri dari berbagai macam kitab dalam pengertian tema. Dan masing-masing dari kitab tersebut terdiri dari berbagai macam subkitab. Seperti kitab al-ibadah, kitab alshalah, kitab, alzakat, kitab al-shaum, kitab al-hajj dan seterusnya.

Lanjut Shahrur meneruskan kajiannya tentang kitab, bahwa jika ia dalambentuk ma'rifah, yakni dengan diberikan alif dan lam, seprti yang tertera dalam QS. Al-Baqarah/2: 2, maka kata tersebut dapat difahami sebagai keseluruhan kandungan mushaf. Karena itu, dengan pengertian seperti ini istilah 'al-kitab' merujuk kepada pengertian kumpulan berbagai macam tema (almawaad) yang diwahyukan kepada nabi Muhammad saw. Pendapat Shahrur dapat disepahamkan dengan Ibnu Katsir yang juga mengartikan kata "al-kitab" dengan Al-Qur'an, namun Ibnu Katsir lebih menunjukkan kepada makna kitab secara umum karena mencakup kitab Taurat dan

\footnotetext{
${ }^{65}$ Muhammad Shahrur, Prinsip dan Dasar Hermeneutika Kontemporer..., h. 69.

${ }^{66}$ Muhammad Shahrur, Prinsip dan Dasar Hermeneutika Kontemporer..., h. 69.
} 
Injil. ${ }^{67}$ Kemudian Shahrur menyatakan QS. Al-Fatihah disebut juga sebagai "fatihat alkitab". 68 Karena ia menjadi pembuka keseluruhan tema-tema yang dikandung Al-Qur'an, baik secara tulisan karena ia dibaca di setiap raka'at sha; at dan juga bisa disebut sebagai Umm al-Kitab, induk AlQur'an. $^{69}$ Kitab ini menurut Shahrur memuat tema-tema utama, seperti, kitab alghaib $^{70}$ dan kitab ibadah dan akhlaq. ${ }^{71}$

Darui pemaparan di atas, Shahrur menegaskan terdapat dua macam kitab, kitab yang pertama (dengan kata kitab) berhubungan dengan prilaku manusia, seperti kitab shalat, zakat, puasa, hajji dan lain sebagainya, menurut Shahrur pada jenis kitab pertama ini manusia tidak diwajibkan secara mutlak, karena manusia memiliki kemampuan memilih untuk terikat dan terlepas darinya. Sedangkan kitab yang kedua (dengan al-kitab, dalam bentuk ma'rifah) terdiri dari hukum alam dan hukum kehidupan manusia, seperti kematian, hari kiamat dan kitabhari kebangkitan. Semua jenis kitab ini (dalam bentuk al-kitab) berlaku bagi seluruh manusia tanpa adanya pengecualian dan manusia tidak memiliki kemampuan untuk menolak atau menghindarinya. ${ }^{72}$

Penafsiran hermeneutis Shahrur berlanjut berkenaan dengan kata al-Dzikr, kata yang ditolak olehnya sebagai sebuah bentuk sinonim dari kata al-Kitab dan $\mathrm{Al}$ Qur'an. Berkenaan dengan penjelasan ini, Shahrur berusaha menjelaskan firman

${ }^{67}$ Ibnu Katsir, Tafsir Al-Qur'an al-'Azhim, (Kairo: Dar al-Hadits, 2002), jil. I, cet. ke-I, h. 53.

${ }^{68}$ Muhammad Shahrur, Prinsip dan Dasar Hermeneutika Kontemporer..., h. 69.

${ }^{69}$ Ibnu Katsir, Tafsir Al-Qur'an al- 'Azhim..., h. 15 .

${ }^{70}$ QS. Al-Baqarah/2: 2.

${ }^{71}$ QS. Al-Baqarah/2: 3 .

${ }^{72}$ Muhammad Shahrur, Prinsip dan Dasar Hermeneutika Kontemporer..., h. 69-70.
Allah swt. QS. Al-Hijr/15: 6, 9. Dan QS. Shad/38: 1. Menurutnya kata al-Dzikr yang terdapat dalam QS Al-Hijr/15: 6 dan 9 dan QS. Shad/38: 1.diketahui bahwa kata ini difirmankan dalam bentuk ma'rifah (definit) karena diawali dengan pembubuhan alif dan lam. Namun pada QS. Shad/38:1 term Al-Qur'an dan al-dzikr didahului dengan kata " $d z i$ " yang menandakan sifat sesuatu (memiliki sebuah sifat tertentu), bukan pada entitas itu sendiri. Firman wa al-Qur'an dzi aldzikr dapat dipahami "dan al-Qur'an adalah pemilik al-dzikr". ${ }^{73}$ Lebih lanjut Shahrur menegaskan berkenaan Al-Qur'an dan Al-Dzikr, ${ }^{74}$

Al-Qur'an merupakan kumpulan seperangkat aturan hukum yang bersifat objektif dan mengatur segala eksistensi, fenomena perubahan alam dan peristiwa dan atau perilaku yang terjadi dalam kehidupan manusia. Pada bentuk dasarnya Al-Qur'an tidak berbentuk linguistik, kemudian oleh Allah swt. diubah menjadi berbentuk linguistik seperti yang diungkapkan Allah swt. yang terdapat dalam QS. Al-Zukhruf/43: 3. Proses pengubahan Al-Qur'an menjadi berbentuk bahasa manusia dalam format linguistic Arab berlangsung secara sempurna yang bentuk finalnya berupa bentuk bahasa literal (shighah manthuqah)

Penjelasan Shahrur mengenai AlQur'an yang diterima manusia merupakan hasil dari proses linguistik yang diproses Allah swt. serta menggambarkan keseluruhan proses serta rangkaian yang dialami manusia. Karenanya ia menyebut bahwa term al-dzikr sebagai bentuk pengubahan (Al-Qur'an) menjadi

\footnotetext{
${ }^{73}$ Muhammad Shahrur, Prinsip dan Dasar Hermeneutika Kontemporer..., h. 80.

${ }^{74}$ Muhammad Shahrur, Prinsip dan Dasar Hermeneutika Kontemporer..., h. 80.
} 
berbentuk bahasa manusiawi yang secara literal berupa linguitik Arab. Yang menurutnya kemudian, bentuk seperti inilah yang digunakan untuk membaca dan memahami Al-Qur'an. ${ }^{75}$ Penafsiran Shahrur memang berbeda dengan beberapa ulama tafsir lain yang memahaminya sebagai adanya pemisahan antara AlQur'an dengan Dzikr, Al-Qur'an dipahami sebagai kitab yang diturunkan kepada nabi Muhammad saw. sedangkan Dzikr sebagi sebuah aktifitas Al-Qur'an yang memberikan peringatan yang melalui AlQur'an Allah swt. memberikan peringatan. $^{76}$

Linguistik Arab yang menjadi media dan instrument yang digunakan Al-Qur'an memang telah dijelaskan dalam QS. AlAnbiya/21: 10,

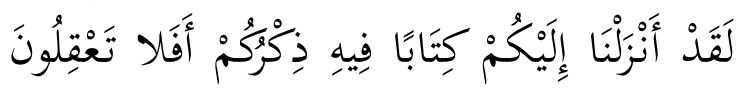

(1.)

Sungguh telahKami turunkan kepadamu sebuah Kitab (Al-Qur'an) yang di dalamnya terdapat peringatan bagimu. Maka apakah kamu tidak mengerti?"

Menurut Shahrur, bahwa di dalam Al-Qur'an terdapat bentuk wahyu berbahasa Arab yang dapat diartikulasikan dalam media bahasa Arab murni, karenanya akan sangat berkesesuaian dengan redaksi "fihi dzikrikum. ${ }^{77}$ Sehingga berdasarkan penggunaan bahasa Arab sebagai sebuah media yang digunakan AlQur'an untuk menyampaiakan setiap firman Allah swt. dalam Al-Qur'an menunjukkan kemuliaan dan keluhuran

\footnotetext{
${ }^{75}$ Muhammad Shahrur, Prinsip dan Dasar Hermeneutika Kontemporer..., h. 80

${ }^{76}$ Abi Bakar Jabir al-jazairi, Aysar alTafasir, (Madinah: Maktabah al-'Ulum wa alHikam, 2003), Jil. II, cet. ke-VI, h. 1099.

${ }^{77}$ Muhammad Shahrur, Prinsip dan Dasar Hermeneutika Kontemporer..., h. 80-81..
}

bahasa Arab. Hal itu karena ia digunakan oleh teks suci dan mulia. Demikian beberapa penafsiran Shahrur yang menggunakan pendekatan hermeneutika dengan keteguhannya menolak sinonim atau yang biasa disebut dengan asinonimisasi agar Al-Qur'an dapat dipahami secara utuh dan komprehensif dan sesuai dengan makna yang dimaksud yang telah terwakili teks yang telah dibawa Al-Qur'an yang disampaikan kepada manusia.

\section{E. Penutup}

Sebagai sebuah petunjuk dan firman Allah swt. Al-Qur'an sudah sejatinya dapat dipahami dan dimengerti oleh manusia sebagai audiens dan objek firman dengan bahasa manusia. Berbagai upaya yang dilakukan telah banyak melahirkan teksteks turunan (tafsir) akibat dari proses dialogis-dialektis-akademis dan tidak kurang ratusan bahkan ribuan eksemplar telah dilahirkan sebagai akibat dari aktifitas penafsiran ini (exegesist) pun tentunya menggunakan berbagai metode dan pendekatan yang berragam. Di antara pendekatan dan metode yang digunakan adalah hermenutika, metode penafsiran dengan model ini memang pada awalnya diterapkan oleh Barat untuk membahas otentisitas Bible sebagai kitab suci ummat Kristiani, namun belakangan, hermeneutika menarik untuk dipelajari dan kemudian dikembangkan oleh para sarjana muslim dalam penafsiran Al-Qur'an sehingga dari aktifitas hermenutika ini melahirkan banyak pemikir muslim-walau kemudian eksistensi dan kiprah mereka dalam hermenutika Al-Qur'an tidak sedikit menghadapi hadangan bahkan penolakan, namun demikian sebagai sebuah cara dan metodologi, hermeneutika layak mendapatkan tempat dalam konteksnya 
sebagai sebuah perangkat keilmuan yang dinilai dapat mendukung capaian pemahaman Al-Qur'an yang lebih komprehensif.

\section{DAFTAR PUSTAKA}

Al-Jazairi, Abi Bakr, Aysar al-Tafasir, Maktabah al-Munawarah

Al-Maqdisi, Fath al-Rahman, Maktabah Dahlan, Bandung:tt, hal. 380-381.

Anwar, Hamdani, Pengantar Ilmu Tafsir, Jakarta: Penerbit Fikahati, 1995,

Abdul Haris Rasyidi dalam. Kajian Islamologi tentang Tradisi Pembaharuan dan Modernitas. Telaah Buku Dirasaat Islamiyyah Hassan Hanafi, Jurnal Islam Nusantara, Vol. 1. No. 2 edisi. JuliDesember 2017.

Ahmala dalam, Lahirnya Hermeneutika dan Ilyas Supena dalam, Rudolf Bultman, Hermeneutika Teologis Rudolf Bultman, dalam Hermeneutika Transendental, editor, Nafisul 'Atho dan Arif Fahrudin, (Yogyakarta: Ircisod, 2003)

Abi Bakar Jabir Al-Jazairi, Aysar alTafasir, (Madinah: Maktabah al'Ulum wa al-Hikam, 2003)

Abdul Haris Rasyidi dalam. Kajian Islamologi tentang Tradisi Pembaharuan dan Modernitas. Telaah Buku Dirasaat Islamiyyah Hassan Hanafi, Jurnal Islam Nusantara, Vol. 1. No. 2 edisi. JuliDesember 2017.

Ayman A. El-Desouky, Between Hermenutics Provenance and Textuality: The Qur'an and the questions of Methode in Approaches to World Literature, (SOAS University of London), h. 14.
Diunggah tanggal 24 Juli 2018 Pukul. 10:30 WIB.

Devi Muharrom Sholahudin, Studi Metodologi Tafsir Hassan Hanafi, Jurnal Studia Qur'anika, Vol. 14. No. 1, Maret, 2016.

Faiz, Fakhruddin, Hermeneutika Qur'ani, Antara Teks, Konteks, dan Kontekstualisasi, (Qalam, Yogyakarta: 2003).

Ilham B. Saenong, Hermeneutika Pembebasan, Metodologi Tafsir AlQur'an Menurut Hassan Hanafi, (Bandung: Teraju, 2002), cet. ke-I, 142.

Ibnu Katsir, Tafsir Al-Qur'an al-'Azhim, (Kairo: Dar al-Hadits, 2002)

Kurdi, dkk., Hermeneutika al-Qur'an dan Al-Hadits, (Yogyakarta: Elsaq Press, 2010), cet. ke-I, h. 296.

Komaruddin Hidayat, Memahami Bahasa Agama, Sebuah Kajian Hermeneutik, (Jakarta: Paramadina1996)

Komaruddin Hidayat, Menafsirkan Kehendak Tuhan, (Bandung: Teraju, 2004)

Muhammad Shahrur, Prinsip dan Dasar Hermeneutika Kontemporer, terj. Sahiron Syamsuddin, (Yogyakarta: Elsaq Press, 2004) .

Mustaqim, Abdul, Madzahibut Tafsîr: Peta Metodologi Penafsiran Al-Qur'an Periode Klasik Hingga Kontemporer, (Nun Pustaka, Yogyakarta: 2003)

Nawawi, Rif'at Syauqi, Rasionalitas Tafsir Muhammad Abduh, Kajian Masalah Aqidah dan Ibadah, Jakarta: Paramadina, 2002, cet. ke-I, hal. 87.

Nata. Abuddin, Metodologi Studi Islam, (Rajawali Press, Jakarta: 2001)

Shihâb, M Quraish, Tafsir al-Misbâh, Pesan, kesan dan keserasian alQur'an, (Lentera Hati, Jakarta: 2005), cet. ke-3, hal. V. vol. 1. 
Summa, Muhammad Amin, Studi Ilmuilmu Al-Qur'an (Pustaka Firdaus, Jakarta: 2001)

Syarqâwî, Iffat Muhammad, Ittijahâat al-

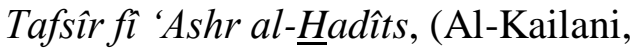
Kairo: 1972), hal. 182.

Syurbasy, Ahmad, Sejarah Perkembangan Tafsir al-Qr'an al-Karim, (Kalam Mulia, Jakarta: 1999) 
Model Pembelajaran Kooperatif Perspektif Al-Qur'an

Rausyan Fikr. Vol. 15 No.1 Maret 2019. ISSN. 1979-0074 e-ISSN. 9772580594187 | 96 